\title{
Does the seed rain limit recruitment, regeneration, and plant community dynamics?
}

\author{
Randall W. Myster \\ RandallW.Myster (myster@okstate.edu, www.researchgate.net/profile/Randall_Myster), Biology Department, \\ Oklahoma State University, Oklahoma City, OK 73107 USA
}

\begin{abstract}
The role of the seed rain in affecting recruitment, regeneration, and plant community dynamics continues to be debated. Studies show that seed limitation for recruitment is more likely as ecosystems become colder and more species-poor, as in boreal forests, and for species that have large seeds and short-lived seed banks. Even if there is a limiting effect of the seed rain for recruitment, however, clumping seen for mature trees and other evidence suggests that its effect diminishes with time. I posit that the dynamics of plant communities are largely determined where the seed rain is abundant and not limiting - in local spaces close to dispersing plants. Putting all the evidence together, I conclude that it is what happens to seeds after dispersal-such as loss to predation and pathogenic attack, or germination success resulting from environmental tolerances - that has a greater effect on recruitment, regeneration and plant community dynamics. And thus the variation in the workings of seed fate mechanisms and environmental tolerances, deserve more research attention. The importance of the seed rain in affecting recruitment of individual plants, regeneration of individual plants, and plant community dynamics has been over-emphasized in plant modeling and theory.
\end{abstract}

Keywords: germination; neighborhood space; phytospace; seed pathogens; seed predation.

\section{Introduction}

It is easy to believe that whatever limits recruitment in a plant community will have a major impact on its regeneration and dynamics, and researchers have dichotomized recruitment as either seed-limited or microsite-limited (Eriksson \& Ehrlen 1992). Populations are seed-limited when the rate of seed supply is low relative to the availability of suitable microsites or are microsite-limited when the rate of seed supply is sufficient to ensure that all suitable microsites are occupied but a combination of other seed fate mechanisms and environmental tolerances constrain recruitment (Poulsen et al. 2007). It has been suggested, however, that seed limitation and microsite limitation are endpoints on a continuum, and that real plant communities lie at different points along that continuum (Poulsen et al. 2007).

While several studies have presented evidence for seed limitation (e.g., Kollmann and Pirl 1995, Laman 1996, Turnbull et al. 2000, Wijdeven and Kuzee 2000, Herrera and Laterra 2009, Du et al. 2011, BustamanteSanchez and Armesto 2012, Salazar et al. 2012), other studies have suggested that the role of seed limitation, as a process influencing plant communities, may be uncertain (Svenning and Wright 2005) and even unimportant (Webb and Peart 2001). Indeed, natural levels of seed rain may be unreported or even unknown (Myers and Harms 2009), and seed dispersal studies may have been too short and dispersal itself too hard to follow (Wang and Smith 2002, Ehrlen et al. 2006). Further, 
studies that claim seed limitation may not have examined it at scales commensurate with adult tree sizes (Kobe and Vriesendorp 2009) and that, even if it exists, seed limitation may be found predominately in cold, speciespoor ecosystems (e.g., boreal forests: Pinno et al. 2013, Viglas et al. 2013) or for select species that have large seeds and short-lived seed banks (Clark et al. 2007).

A common approach of researchers claiming seed limitation has been to seek correlations between the number of seeds for a species found in seed traps and the seedling distribution patterns of the same species near the seed trap (Dalling et al. 2002). And indeed, a lognormal pattern from the dispersing "maternal" plant is a good fit for both seed dispersal and seedling dispersion patterns (Myster and Pickett 1992, Martin and Canham 2010). Such correlation analysis, however, is indirect evidence of seed limitation at best unless we know the availability of suitable microsites for germination and seedling establishment, and the strength of other seed and seedling fate mechanisms and environmental tolerances within those microsites. Another approach has been to add seeds to plots and then, after some time, compare seedling densities in those plots to seedling densities in control plots (Aicher et al. 2011). Such experiments, however, say little about the absolute degree of seed limitation or the relative importance of seed supply compared with other factors in natural communities (Nathan and MullerLandau 2000, Clark et al. 2007).

A common problem in many of these past studies is that they do not show clearly when, where and under what conditions seed limitation may occur; neither do they distinguish between recruitment, regeneration, and plant community dynamics. This is crucial if we are to understand how these separate aspects of plant life interact and influence each other, and how they create the plant population and community patterns that plant researchers study.

\section{How to proceed}

Two patterns are almost ubiquitous in plant communities: First, mature plants of the same species are not spatially arranged randomly nor (very rarely) uniformly, but instead clump at local spatial scales (Myster and Pickett 1992, Valencia et al. 2004, Myster and Malahy 2012). This indicates that regeneration occurs locally, not far from the maternal plant, and that any local seed limitation for recruitment diminishes over time (MullerLaudau et al. 2002). Likewise, studies for trees show density-dependent seed/seedling mortality (the JanzenConnell hypothesis: Janzen 1970) to be rare (Wright 1999, Wright 2002) and tree morality to be largely random after trees are $1 \mathrm{~cm}$ diameter at breast height (Wills \& Condit 1999). The importance of local spaces in plant community dynamics is also seen in the "creep" found at ecotones as species move back and forth close to the boundary (and the maternal trees) between two plant communities (Myster 2012a). And second, seed rain density decreases sharply as you move away from the maternal plant; that is to say, seed dispersal is highly localized (Clark 1998, Martin and Canham 2010), with some variation due to factors such as mast years and low production years (Norghauer and Newbery 2015).

These two patterns strongly suggest that the seed rain rarely limits regeneration in plant communities and thus has a relatively small effect on plant community dynamics. Now while it is (trivially) possible to find a spatial scale large enough where seeds of any given species do not disperse (Eriksson and Ehrlen 1993, Munzebergova 2004, Munzbergova and Herben 2005), that by itself surely is not evidence of seed limitation. Taken together, these facts suggest that it is in local spaces close to plants where most plant community dynamics is determined (Kobe and Vriesendorp 2009) and, because the seed rain is usually not limiting there, I posit that the importance of its role in affecting plant community dynamics has been over-emphasized in plant population/community modeling and theory.

Much of these local spaces are either part of a plant's neighborhood space (Turkington and Harper 1979) — the space outside a plant's physical body where a plant influences, and/or may be influenced by, other plantsor a plant's phyto-space (Myster 2012b) —its local biomass and necromass taken together. Neighborhood spaces may overlap (Stoll and Weiner 2000, Weiner et al. 2001) and their exact definition and extent continues to be a matter of research and debate (e.g., plant competition experiments have used circles of radius $12.5 \mathrm{~cm}$ with the plant in the center: Naeem et al. 2000). The close relationship between these two spaces and local spaces in a plant community is critical to the plant-plant replacement process and the plant community dynamics it creates (Myster 2012b). A good field test of these conjectures would include seed rain sampling and seed addition, and seed/seedling/sapling field experiments involving seed/seedling fate mechanisms and tolerances in the same area, at the same time and involving the same species.

\section{What does limit recruitment, regeneration and plant community dynamics?}

If the seed rain is not generally limiting recruitment, regeneration or plant community dynamics, then what is? Obviously, we should examine the fate of the seed rain, i.e., what happens to the seeds and seedlings after dispersal (Calvino-Cancela 2007). This includes mechanisms involving seed predation, seed pathogenic attack, secondary seed dispersal, seedling herbivory and seedling pathogenic attack, and environmental tolerances for germination, dormancy/seed longevity (the seed bank) and seedling competition between near neighbors 
(Myster 2003). Consequently, one of my (and others') research foci for many years has been field studies involving such post-dispersal seed/seedling fate mechanisms and environmental tolerances. They consistently show seed predation determining the fate of the majority of seeds in both temperate and tropical forests, fields and grasslands (Schupp 1988, Myster and Pickett 1993, Notman and Gorchov 2001, Holl 2002, Myster 2003, Vieira and Scariot 2006, Myster 2007, Haught and Myster 2008, Myster 2012a, Myster 2015). These studies have used seeds of common plant species - differing in size, dispersal mechanism, family and longevity - and experimental manipulation within the local spaces of dispersing adults.

It is important to realize that even after suffering such large seed losses, the species in these studies do manage to recruit seedlings, and regenerate into mature plants. This must be due to critical sources of variation in how these mechanisms and environmental tolerances work, such as variation among species, variation among microsites created by tree fall, conversion to agriculture and litter, variation among different seasons, variation among different years and variation at different spatial scales. I suggest that these sources of variation in seed/seedling fate mechanisms - like predation and seed pathogens (e.g., Ohanlon and Kotanen 2004) - and in environmental tolerances - e.g. for germination (e.g., Ahlgren 1970) - are generally much more important than variation in seed rain for determining an individual plant's recruitment and regeneration success, and in determining the resulting plant community dynamics - and thus should receive greater emphasis in future field studies.

In sum, to answer the components of the title question: (1) Does the seed rain limit recruitment of individual plant species? Studies suggest that it may for a relatively few species in a relatively few plant communities at some non-local spatial scales, but in general what happens after dispersal-in the critical local spaces where the seed rain is abundant and recruitment is occurring (as shown by clumping patterns of mature plants) - has a much greater effect on plant recruitment; (2) Does the seed rain limit regeneration of individual plant species? Even for those relatively few species whose recruitment is limited by the seed rain, studies suggest those effects diminish with time (again shown by clumping patterns of mature plants) and so the seed rain has little effect on plant regeneration; and (3) Does the seed rain limit plant community dynamics? The answers to the first two parts of this question taken together strongly suggest that the seed rain has only a minimal effect on plant community dynamics and, consequently, also on the plant-plant replacement process (Myster 2012b, Myster 2017) that creates it.

\section{Acknowledgements}

I thank B. Shykoff, M. Partel, M. Palmer, K. Thompson, P. Bernier, B. Schamp, C. LaCroix, C. Fox, B. Foster, L. Turnbull, E. Seabloom, L. Sandhu, J. Ross, K. Gross and J. Bascompte for commenting on a past draft of the manuscript.

\section{Referees}

Nicholas Brokaw - nvlbrokaw@lternet.edu

Institute for Tropical Ecosystem Studies

Lonnie Aarssen - aarssenl@queensu.ca

Queen's University

\section{References}

Ahlgren, C.E. 1970. Some effects of prescribed burning on Jack Pine reoduction in northeastern Minnesota. University of Minnesota Agricultural Experiment Station Miscellaneous Report 94 Forestry Series 5.

Bustamante-Sanchez, M.A., and J.J. Armesto. 2012. Seed limitation during early forest succession in a rural landscape on Chiloe island, Chile: implications for temperate forest restoration. Journal of Applied Ecology 49:1103-1112. CrossRef

Calvino-Cancela, M. 2007. Seed and microsite limitations of recruitment and the impacts of postdispersal seed predation at the within population level. Plant Ecology 192:35-44. CrossRef

Clark, C.J., Poulsen, J.R., Levey, D.J., and C.W. Osenberg. 2007. Are plant populations seed limited? A critique and meta-analysis of seed addition experiments. American Naturalist 170:128-142,

Clark, J.S. 1998. Why trees migrate so fast: Confronting theory with dispersal biology and the paleorecord. American Naturalist 152:204-224. CrossRef

Dalling, J.W., Muller-Landau, H.C., Wright, S.J., and S.P. Hubbell. 2002. Role of dispersal in the recruitment limitation of Neotropical pioneer species. Journal of Ecology 90:714-727. CrossRef

Du, Y., Mi, X., and K. Ma. 2011. Comparison of seed rain and seed limitation between community understory and gaps in a subtropical evergreen forest. Acta Oecologia 10:1-9.

Ehrlen, J., Munzbergova, Z., Diekmann, M., and O. Eriksson. 2006. Long-term assessment of seed limitation in plants: results from an 11-year experiment. Journal of Ecology 94:1224-1232. CrossRef

Eriksson, O., and J. Ehrlen. 1992. Seed and microsite limitation of recruitment in plant populations. Oecologia 91:360-364. CrossRef 
Harper, J.L. 1977. Population biology of plants. Academic Press, NY.

Haught, J.A., and R.W. Myster. 2008. Effects of species, density, season and prairie-type on seed predation in Oklahoma. American Midland Naturalist 159:482488. CrossRef

Herrera, L.P., and P. Laterra. 2009. Do seed and microsite limitation interact with seed size in determining invasion patterns in flooding Pampa grasslands? Plant Ecology 201:457-469. CrossRef

Holl, K.D. 2002. Effect of shrubs on tree seedling establishment in an abandoned tropical pasture. Journal of Ecology 90:179-187. CrossRef

Janzen, D.H. 1970. Herbivores and the number of tree species in tropical forests. American Naturalist 104:501-528. CrossRef

Kobe, R.K., and C.F. Vriesendor. 2009. Size of sampling unit strongly influences detection of seedling limitation in a wet tropical forest. Ecology Letters 12:220-228. CrossRef

Kollmann, J., and M. Pirl. 1995. Spatial pattern of seed rain of fleshy-fruited plants in a scrubland-grassland transition. Acta Oecologia 16:313-329.

Laman, T.G. 1996. Ficus seed shadows in a Bornean rain forest. Oecologia 107:347-355. CrossRef

Muller-Landau, H.C., Wright, S.J., Calderon, O., Hubbell, S.P., and R.B. Foster. 2002. Assessing recruitment limitation: concepts, methods and casestudies from a tropical forest. Pages 35-53 In Levey, D.J., Silva, W.R. and M. Galetti. (eds). Seed dispersal and frugivory: ecology, evolution and conservation. CABI Publishing, Wallingford, UK. CrossRef

Munzbergova, Z. 2004. Effect of spatial scale on factors limiting species distributions in dry grassland fragments. Journal of Ecology 92:854-867. CrossRef

Munzbergova, Z., and T. Herben. 2005. Seed dispersal, microsite, habitat and recruitment limitation: identification of terms and concepts in studies of limitations. Oecologia 145:1-8. $\underline{\text { CrossRef }}$

Myers, J.A., and K.E. Harms. 2009. Seed arrival, ecological filters, and plant species richness: a metaanalysis. Ecology Letters 12:1250-1260. CrossRef

Myster, R.W. 2003. Seed regeneration mechanisms over fine spatial scales on recovering Coffee plantation and pasture in Puerto Rico. Plant Ecology 166:199205. CrossRef

Myster, R.W. 2007. Neotropic post-agricultural seed predation. Pages 216-220 In Post-agricultural succession in the Neotropics. Myster, R.W. (ed). Springer-Verlag, Berlin.

Myster, R.W. 2012a. Ecotones between forest and

Myster, R.W. 2012b. Plants replacing plants: the future of community modeling and research. The Botanical Review 78:2-9. CrossRef

Myster, R.W. 2015. Seed predation, pathogens and germination in primary vs. secondary Cloud forest at
Maquipucuna Reserve, Ecuador. Journal of Tropical Ecology 31:375-378. CrossRef

Myster, R.W. 2017. Conclusions, synthesis and future directions. Pages 197-204 in Forest structure, function and dynamics in Western Amazonia. Myster, R.W. (ed). Wiley-Blackwell, Oxford, UK. CrossRef

Myster, R.W., and M. Malahy. 2012. Testing aggregation hypotheses among Neotropical trees and shrubs: results from a 50-ha plot over 20 years of sampling. Revista de Biologia Tropical 60:1015-1023. CrossRef

Myster, R.W., and S.T.A. Pickett. 1992. Effects of palatability and dispersal mode on spatial patterns of tree seedlings in old fields. Bulletin of the Torrey Botanical Club 119:145-151. CrossRef

Myster, R.W., and S.T.A. Pickett. 1993. Effects of litter, distance, density and vegetation patch type on postdispersal tree seed predation in old fields. Oikos 66:381-388. CrossRef

Naeem, S., Knops, J.M.H., Tilman, D., Howe, K.M., Kennedy, T., and S. Gale. 2000. Plant diversity increases resistance to invasion in the absence of covarying factors. Oikos 91:97-108. CrossRef

Nathan, R., and H.C. Muller-Landau. 2000. Spatial patterns of seed dispersal, their determinants and consequences for recruitment. Trends in Ecology and Evolution 15:278-285. CrossRef

Norghauer, J.M., and D.M. Newbery. 2015. Tree size and fecundity influence ballistic seed dispersal of two dominant mast-fruiting species in a tropical rain forest. Forest Ecology and Management 338:100113. $\underline{\text { CrossRef }}$

Notman, E., and D.L. Gorchov. 2001. Variation in postdispersal seed predation in mature Peruvian low-land tropical forest and fallow agricultural sites. Biotropica 33:621-636. CrossRef

O' Hanlon, D.L., and P.M. Kotanen. 2004. Evidence that fungal pathogens inhibit recruitment of a shadeintolerant tree, white birch (Betula papyrifera), in understory habitats. Oecologia 140:650-653. CrossRef

Pinno, B.D., Errington, R.C., and D.K. Thompson. 2013. Young jack pine and high severity fire combine to create potentially expansive areas of understocked forest. Forest Ecology and Management 310:517522. CrossRef

Poulsen, J.R., Osenberg, C.W., Clark, C.J., Level, D.J., and B.M. Bolker. 2007. Plants as reef fish: fitting the functional form of seedling recruitment. American Naturalist 170:167-183. CrossRef

Ronce, O. 2007. How does it feel to be a rolling stone? Ten questions about dispersal evolution. Annual Review of Ecology and Systematics 38:231-253. CrossRef 
Salazar, A., Goldstein, G., Franco, A.C., and F. MirallesWilhelm. 2012. Seed limitation of woody plants in Neotropical savannas. Plant Ecology 213:273-287. CrossRef

Schupp, E.W. 1988. Seed and early seedling predation in the forest understory and in tree fall gaps. Oikos 51:71-78. CrossRef

Stoll, P., and J. Weiner. 2000. A neighborhood view of interactions among individual plants. Pages 11-27 in: The geometry of ecological interactions: simplifying spatial complexity. Dieckmann, U., Law, R., Metz, J.A.J. (eds). Cambridge University Press. Cambridge University, UK. $\underline{\text { CrossRef }}$

Turkington, R., and J.L. Harper. 1979. The growth, distribution and neighbor relationships of Trifolium repens: a permanent pasture. I. Ordination, pattern and contact. Journal of Ecology 67:201-218. CrossRef

Turnbull, L.A., Crawley, M.J., and M. Rees. 2000. Are plant populations seed-limited? A review of seed sowing experiments. Oikos 88:225-238. CrossRef

Valencia, R., Foster, R. B., Villa, G., Condit, R., Svenning, J. C., Hernandez, et al. 2004. Tree species distributions and local habitat variation in the Amazon: large forest plot in eastern Ecuador. Journal of Ecology 92:214-229. CrossRef

Vieira, D.L.M., and A. Scariot. 2006. Effects of logging, liana tangles and pasture on seed fate of dry forest tree species in Central Brazil. Forest Ecology and Management 230:197-205. CrossRef

Viglas, J.N., Brown, C.D., and J.F. Johnstone. 2013. Age and size effects on seed productivity of northern black spruce. Canadian Journal of Forest Research 43:534543. CrossRef

Wang, B.C., and T.B. Smith. 2002. Closing the seed dispersal loop. Trends in Ecology and Evolution 17:379-385. CrossRef

Webb, C.O., and D.R. Peart. 2001. High seed dispersal rates in faunally intact tropical rain forest: theoretical and conservation implications. Ecology Letters 4:491-499. CrossRef

Weiner, J., Stoll, P., Muller-Landau, H., and A. Jasentuliyana. 2001. The effect of density, spatial pattern, and competitive symmetry on size variation in simulated plant populations. American Naturalist 158:438-450. CrossRef

Wijdeven, S.M.J., and M.E. Kuzee. 2000. Seed availability as a limiting factor in forest recovery processes in Costa Rica. Restoration Ecology 8:414424. CrossRef

Wills, C., and R. Condit. 1999. Similar non-random processes maintain diversity in two tropical rainforests. Proceedings of the Royal Society of London Biologists 266:1445-1452. CrossRef

Wright, S.J. 1999. Plant diversity in tropical forests. Pages 449-472 in: Handbook of functional Plant
Ecology. Pugnaire, F. I., and F. Valladares (eds) Marcel Dekker, NY.

Wright, S.J. 2002. Plant diversity in tropical forests: a review of mechanisms of species coexistence. Oecologia 130:1-14. CrossRef 